\title{
Effects of alloplastic graft material combined with a topical ozone application on calvarial bone defects in rats
}

\author{
N. Laçin' , B.S. İzol², E. Gökalp Özkormaz³ , B. Deveci ${ }^{4}$ E. Deveci ${ }^{3}$ \\ ${ }^{1}$ Department of Oral and Maxillofacial Surgery, Faculty of Dentistry, University of Katip Çelebi, Izmir, Turkey \\ 2Department of Periodontology, Faculty of Dentistry, University of Bingöl, Turkey \\ ${ }^{3}$ Department of Histology and Embryology, Faculty of Medicine, Dicle University, Diyarbakır, Turkey \\ ${ }^{4}$ Department of Periodontology, Faculty of Dentistry, University of Dicle, Diyarbakir, Turkey
}

[Received: 19 June 2019; Accepted: 20 July 2019]

Background: This study presents the evaluation of the damage in the bone tissue resulting from a calvarial defect in rats and the efficiency of exposure to an ozone application with an alloplastic bone graft on the calvarial bone damage.

Materials and methods: Wistar male rats $(n=56)$ were divided into four groups: a control group $(n=14)$, defect and ozone group $(n=14)$, defect and graft group $(n=14)$, and defect, graft, and ozone group $(n=14)$. Under anaesthesia, a circular full-thickness bone defect was created in all groups, and the experimental groups were further divided into two sub-groups, with 7 rats in each group sacrificed at the end of the $4^{\text {th }}$ and $8^{\text {th }}$ weeks. Bone samples were dissected, fixed in $10 \%$ formalin solution, and decalcified with 5\% ethylene-diamine-tetraacetic acid (EDTA). After the routine follow-up on tissues, immunostaining of osteopontin and osteonectin antibodies was applied to sections and observed under a light microscope.

Results: The control group exhibited osteopontin and osteonectin expression in fibroblasts and inflammatory cells at the end of the $4^{\text {th }}$ week with an acceleration at the $8^{\text {th }}$ week. Ozone administration elucidated new trabecular bone formation by increasing osteoblastic activity. Lastly, our observations underscore that a combination of allograft and ozone application increased the osteoblast, osteocyte, and bone matrix development at the $4^{\text {th }}$ and $8^{\text {th }}$ weeks.

Conclusions: Exposure to an ozone application with an alloplastic bone graft on calvarial bone damage may induce osteoblastic activity, matrix development, mature bone cell formation, and new bone formation in rats. (Folia Morphol 2020; 79, 3: 528-547)

Key words: calvarial defects, osteopontin, osteonectin, rat, immunohistochemistry

\section{INTRODUCTION}

Calvarial bone defects are associated with trauma, pathology, and non-union of a fracture and represent a significant clinical problem [13, 72]. The osteogenic potential of autograft and allografts is known in the field of orthopaedics, plastic surgery, and oral and maxillofacial surgery $[41,67]$. Autograft is the current gold standard treatment for bone grafting; however,

Address for correspondence: E. Deveci, Professor, PhD, Department of Histology and Embryology, Faculty of Medicine, Dicle University, 21280, Diyarbakır, Turkey, tel: +90 4122488001 ext. 4443 (faculty room), fax: +90 412 2488440, e-mail: devecie32@hotmail.com

The experimental part of the study was conducted at The Experimental Research Centre of Dicle University, 21280, Diyarbakır, Turkey. Histopathological examinations of the tissues were evaluated in The Histology and Embryology Laboratory in Medical School of Dicle University, 21280, Diyarbakır, Turkey. 
it is limited by the available volume of graft material, donor site morbidity, and unpredictable bone resorption $[24,27]$. Allografts are good alternatives to bridge defects, but the risk of disease transmission and adverse host immune reactions limits the use of allografts. Therefore, improved strategies are urgently needed to better treat craniofacial bone defects $[25,48]$.

Antioxidants applied in defect-induced bone injuries alone do not prevent bone loss. It has also been reported that the effect of antioxidants is more prominent, especially after graft application. Experimental studies have indicated that osteoprogenitor cell activity is induced when the graft is applied for 4-6 weeks, depending on the type of graft material [66]. Several types of graft material are available. For instance, allografts are provided from donors of different genetic characteristics in the same species [26]. There are limitations in the convenience of graft types, such as the shortage in the usability of autografts, inappropriate characteristics of allografts, and risk of disease transmission in xenografts. For all these reasons, researchers have developed an approach of synthetic graft material use in bone defects.

In an experimental study, it has been reported that hyperbaric oxygen and ozone are equally effective in bone development in rats induced with calvarial defects [32]. In a clinical study with topical ozone application, alveolar bone healing is accelerated using postoperative long-term systemic ozone application [21]. Preparing a superhydrophilic titanium implant functionalised with ozone gas can modulate osteoconductivity and inhibit the inflammatory response to titanium implants. This superhydrophilic surface has been proposed to be useful as an endorsed implantable biomaterial and as a biomaterial for implantation in other tissues [64]. The effect of ozone treatment in combination with autogenous bone grafts on bone healing in rat calvaria has been investigated. Exposure to an ozone application increases new bone formation by autogenous bone graft in the rat calvarial defect model [45].

Clinically, the importance of ossification and fracture healing is well known in rats. It has been reported that exposure to ozone application provides good healing in diabetes [1], oral mucositis [5], surgical treatment of peri-implantitis [30], bone regeneration $[20,70]$, and osteogenesis with calvarial defects in experimental models [59]. Many rodent experimental animals, including rats, have been used to design bone defect models $[7,12,50,53]$. Anatomically, these rodent models were studied in the calvarium, femur, mandible, and spine. The defect of the calvarium and femur in rats is defined as regions that do not require fixation for stabilisation. The calvarial defects are histologically considered an intramembranous model. The bone matrix is considered to be less applicable to biomaterials. In other words, it has been suggested that the bone matrix is more suitable for endochondral bone model studies. For this reason, calvarial defect models should be designed according to appropriate strategies [23]. A smaller size calvarial defect may recover spontaneously; thus, this was taken into account for the purposes of the study. As a result, an $8 \mathrm{~mm}$ calvarial defect was created [36].

Osteonectin protein is involved in the upregulation of mineralisation in osteoblast cells, and cell adhesion in osteoclast cells. Osteonectin is a single chain acidic glycoprotein that is rich in cysteine, which is synthesised by the cells of an osteoblastic lineage that is abundantly expressed in bones undergoing active remodelling. It is connected with type I collagen, calcium, and hydroxyapatite and therefore prevents mineralisation [34]. Osteopontin (also called BSP-1) protein located in the extracellular bone matrix is non-collagenous and acts in bone cell functions [38]. Osteopontin participates in the upregulation of cell adhesion and differentiation in osteoblast cells, and concomitantly in the upregulation of cell adhesion and bone resorption in osteoclast cells [51]. In a study on two different phases of bone belonging to rats, the distribution of $\mathrm{N}$-linked glycoproteins was determined [28]. In another paper, it was noted that bone sialoprotein binds firmly to collagen type I and hydroxyapatite crystals, revealing that sialoprotein and osteopontin are involved in mineralisation $[54,68]$. Bone sialoprotein is closely related to the nucleation of amorphous calcium phosphate [71]. In addition, mice with decreased levels of osteopontin in the bone were reported to be more prone to fractures, depending on the varying amount of calcium bound by osteopontin [65]. Bone, cartilage, dentin, cement, vascular tissue, and epithelial tissue cells express osteopontin [61]. Osteoclasts, differentiated osteoblasts, and osteocytes release osteopontin and act in osteoclast adhesion, resorption, formation, and migration [60]. It is known that in remodelling bone tissue, cells secrete osteopontin. In addition, osteopontin also contributes to the modulation of the inflammatory phase, acting as a pro-inflammatory cytokine [63]. 
In this study, we aimed to show the expression of osteonectin and osteopontin proteins in rats with calvarial defects by exposure to a topical ozone application with an alloplastic graft implant.

\section{MATERIALS AND METHODS}

Ethics and experimental procedure

Approval of the study was obtained from the Experimental Animal Ethics Committee of Dicle University. Experimental animals were obtained from the Health Sciences and Application Centre at Dicle University in Diyarbakir, Turkey. All operations on animals were performed according to the standards in the Guide for the Care and Use of Laboratory Animals (2011, $8^{\text {th }}$ ed.) released by the National Research Council.

A total of 56 healthy male Wistar rats weighing 280 to $300 \mathrm{~g}$ were used for the study.

The individually housed animals were kept in suitable cages under the conditions of a $12 \mathrm{~h}$ light and $12 \mathrm{~h}$ dark cycle at temperatures of $22 \pm 2^{\circ} \mathrm{C}$ at $50-70 \%$ humidity. They were fed a standard pellet diet and water ad libitum. At the end of the experiment, no difference was observed between experimental and control rats in terms of food/water consumption and body weight gain. At the end of the $4^{\text {th }}$ week, 2 rats in the control group, 1 rat in the defect and ozone group, and 1 rat in the defect and graft group were seen to have died. At the end of the $8^{\text {th }}$ week, 2 rats in the control group, 1 rat in the defect and ozone group, 2 rats in the defect and graft group, and 2 rats in the defect, graft and ozone group were found to be dead. The tissues of all dead rats were routinely examined histologically.

The experimental design for the groups was as follows. For all groups, half of the rats were sacrificed at the end of the $4^{\text {th }}$ week, and the remaining half were sacrificed at the end of the $8^{\text {th }}$ week. The following are the group designs:

- control group $(n=14)$ : a calvarial bone defect was created without any treatment, and the wound was sutured;

- defect and ozone group ( $n=14)$ : a calvarial bone defect was created and treated with ozone;

- defect and graft group $(n=14)$ : a calvarial bone defect was created, and alloplastic bone grafts were applied to the defect;

- defect, graft, and ozone group $(n=14)$ : calvarial bone defect was created, and alloplastic bone grafts plus ozone treatment was applied to the defect.

\section{Calvarial defect model and surgical procedure}

Anaesthesia was performed with $3 \mathrm{mg} / \mathrm{kg}$ xylazine (Rompun 2\%; Bayer) and $90 \mathrm{mg} / \mathrm{kg}$ ketamine $\mathrm{HCl}$ i.p. (Eczacıbası, Istanbul) [46]. After the scalp was shaved and disinfected using $70 \%$ alcohol, the open frontal bone was uncovered by an incision. The periosteum was removed with a periosteal elevator and a trephine bur. Then, the full thickness of the calvarial bone defect was created at $8 \mathrm{~mm}$ in diameter. An alloplastic graft material (Bio-Graft-HT, IFGL Bio Ceramics, India) consisting of a combination of porous biphasic $60 \%$ synthetic hydroxyapatite granules and $40 \%$ beta-tricalcium phosphate bone graft granules with a diameter of 350-500 $\mu \mathrm{m}$ was applied in the defect area of the third and fourth groups. In the groups with exposure to ozone, prozone (W\&H, Bürmoos, Austria) at a concentration of $80 \%$ was applied to the prepared graft area from a distance of $1 \mathrm{~mm}$ using a Coro tip applicator. Prozone was administered for $120 \mathrm{~s}$, two times a week with a Coro tip applicator. Subcutaneous tissue was sealed with a $6 / 0$ vicryl suture, and the skin was closed using a $5 / 0$ silk suture. The skin on the calvarium was completely removed, and the defect was taken out with bone forceps [39].

In this experimental study, a calvarial defect model was created, and immunohistochemical observations were evaluated in the four groups. Calvarial defects with ozone and graft application were examined both separately and together. Our purpose was to investigate the relevance of exposure to the ozone application and healing of the calvarial defect at the tissue level immunohistochemically. To show this relationship immunohistochemically, osteonectin and osteopontin expressions were evaluated in all groups.

\section{Immunohistochemical staining}

Samples of calvarial bone were fixed with $10 \%$ formaldehyde solution, decalcified with $5 \%$ ethylene-diamine-tetraacetic acid (EDTA), dehydrated in a graded series of ethanol, and then embedded in paraffin wax. Then, 4-5 $\mu \mathrm{m}$ thick sections were cut with a microtome (Leica, Germany) and placed on coated slides. Sections were brought to distilled water and washed 3 times for $5 \mathrm{~min}$ in phosphate buffered saline (PBS, pH 7.4) (catalogue number \# 10010023, Thermo Fisher Scientific, US). To unmask antigen sites, slides were incubated with EDTA solution in microvawe for $110 \mathrm{~min}$ at $3 \times 90^{\circ} \mathrm{C}$. The sections were washed in 3 times for $5 \mathrm{~min}$ in PBS and incubated with hydrogen peroxide (catalogue 
\# TA-015-HP, Thermo Fisher Scientific, US) for $20 \mathrm{~min}$. Ultra V block (TA-125-UB, Thermo Fisher Scientific, US) was applied to the sections for $8 \mathrm{~min}$ prior to the addition of the primary antibodies, which were left on overnight osteonectin (SPARC Monoclonal Antibody), catalogue \# 33-5500, 1:100; and osteopontin monoclonal antibody, catalogue \# MA5-17180, 1:100, both from Thermo Fisher Scientific, US). The sections were washed 3 times for 5 min in PBS and then were incubated with biotinylated secondary antibody (catalogue \# TP-125-BN, Thermo Fisher Scientific, US) for $14 \mathrm{~min}$. After washing with PBS, streptavidin peroxidase (catalogue \# TS-125-HR, Thermo Fisher Scientific, US) was applied to the sections for $15 \mathrm{~min}$. The sections were washed 3 times for $5 \mathrm{~min}$ in PBS. Diaminobenzidine (catalogue \# TA-012-HDC, Thermo Fisher Scientific, US) was applied to sections for up to $20 \mathrm{~min}$ as a chromogen. Control slides were prepared using the same procedure, without primary antibodies. Counterstaining was done using Harris's haematoxylin for $45 \mathrm{~s}$, dehydrated through ascending alcohol and cleared in xylene (Product Number: HHS32 Sigma, haematoxylin solution, Harris Modified, Sigma-Aldrich, 3050 Spruce Street, Saint Louis, MO, 63103, USA). Slides were mounted with Entellan $^{\circledR}$ (lot: 107961, Sigma-Aldrich, St. Louis, MO, USA) and examined under a light microscope (Olympus, Germany).

\section{Scoring of parameters for immunohistochemistry}

Semi-quantitative scoring $[22,40,42]$ was determined by examining osteoblastic activity, osteocytic activity, osteoclastic activity, and new bone formation in the bone tissue in 15 different regions within the microscope field, and 10 cells were counted in each area for osteonectin and osteopontin expression. These parameters were scored as: $0=$ no change, $1=$ too weak, 2 = weak, $3=$ medium, and $4=$ strong.

\section{Statistical analysis}

Statistical analyses were performed using the SPSS 22.0 programme. The Kruskal-Wallis variance analysis method was used for non-parametric tests in comparison between groups because the data were not distributed according to the Shapiro-Wilk test. According to the Kruskal-Wallis variance analysis, the difference between the groups was statistically significant at $p<0.05$. The comparison of the groups with each other was compared with the Mann-Whitney $U$ test with Bonferroni correction from multiple comparison tests. In the comparison of the pairs between groups, the Bonferroni-corrected Mann-Whitney $U$ test was used for multiple comparison tests.

The statistical results of the scoring model of the histological sections of our study were evaluated in the Biostatistics Department of Dicle University.

\section{RESULTS}

\section{Immunohistochemical results}

For the control group at the $4^{\text {th }}$ week, the osteopontin expression was positive in the inflammatory cells of the calvarial bone. The osteopontin positive expression was observed in some osteoclast cells (Fig. 1a, red arrow), and osteopontin negative expression was observed in newly formed small trabecular bone parts (Fig. 1a, yellow arrow). However, the matrix and osteoblastic activity have not yet increased in the newly formed bone (Fig. 1a, $a^{*}$ ). For the $8^{\text {th }}$ week of the control group, new bone formation was evidenced by the increased activity of the connective tissue cells and osteoblast cells within the defect area. The osteoblast cells around the bone trabeculae showed osteopontin positive expression (Fig. 1b, yellow arrow) at the site of the bone matrix (Fig. 1b, b*). Osteonectin expression in the fibroblast and osteoblast cells (Fig. 1c, yellow arrow) was found to be positive in the control rats for the $4^{\text {th }}$ week. Bone trabeculae increased in the peripheral osteoblastic activity (Fig. 1c, $c^{*}$ ). The expansion of bone trabeculae at the $8^{\text {th }}$ week showed positive osteonectin expression in the osteoblast cells (Fig. 1d, yellow arrow) and matrix structure (Fig. 1d, red arrow, Fig. $\left.1 d^{*}\right)$. In the defect and ozone group, osteopontin expression in the fibroblast, osteoclast, and osteoblast cells showed positive expression at the $4^{\text {th }}$ week and showed osteopontin reaction in new bone trabeculae due to matrix development (Fig. 2a, yellow arrow, Fig. $2 a^{*}$ ). For the $8^{\text {th }}$ week, osteoblastic activity and osteopontin expression in osteocytes (Fig. 2b, yellow arrow) showed a positive reaction. Bone trabeculae and the matrix for new bone formation became evident (Fig. 2b, b*). An increase in connective tissue cells occurred between the calvarial bone and the defect area at the $4^{\text {th }}$ week, whereas the osteonectin expression in the fibroblast and collagen fibres (Fig. 2c, red arrow) and osteoblast cells (Fig. 2c, yellow arrow) was positive (Fig. $2 c, c^{*}$ ). For the $8^{\text {th }}$ week, osteonectin expression increased in fibroblast macrophages and osteoblast cells. Expansion in new bone trabeculae (Fig. 2d, black star) became evident in osteocytes (Fig. 2d, blue arrow), osteon 


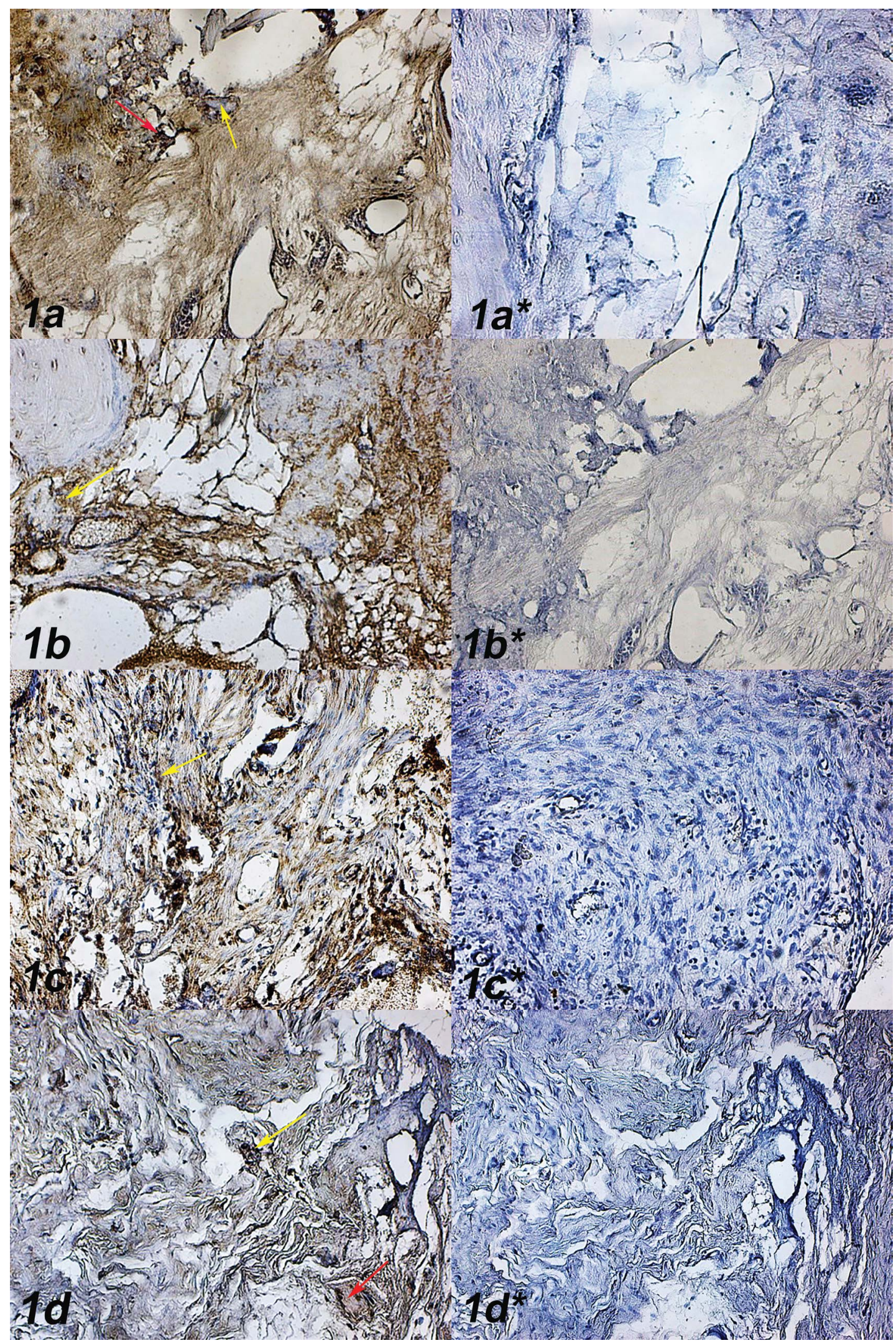

Figure 1. a. Osteopontin immunostaining, control group (4 $4^{\text {th }}$ week), scale bar $=50 \mu \mathrm{m}$; $\mathbf{a}^{*}$. Negative control group ( $4^{\text {th }}$ week), haematoxylin staining, scale bar $=50 \mu \mathrm{m} ; \mathbf{b}$. Osteopontin immunostaining, control group $\left(8^{\text {th }}\right.$ week); $\mathbf{b}^{*}$. Negative control group ( $8^{\text {th }}$ week), haematoxylin staining, scale bar $=50 \mu \mathrm{m}$; c. Osteonectin immunostaining, control group ( $4^{\text {th }}$ week), scale bar $=50 \mu \mathrm{m} ; \mathbf{c}^{*}$. Negative control group ( $4^{\text {th }}$ week), haematoxylin staining; scale bar $=50 \mu \mathrm{m}$; d. Osteonectin immunostaining, control group ( $8^{\text {th }}$ week), scale bar $=50 \mu \mathrm{m}$; $\mathbf{d}^{*}$. Negative control group ( $8^{\text {th }}$ week), haematoxylin staining, scale bar $=50 \mu \mathrm{m}$. 


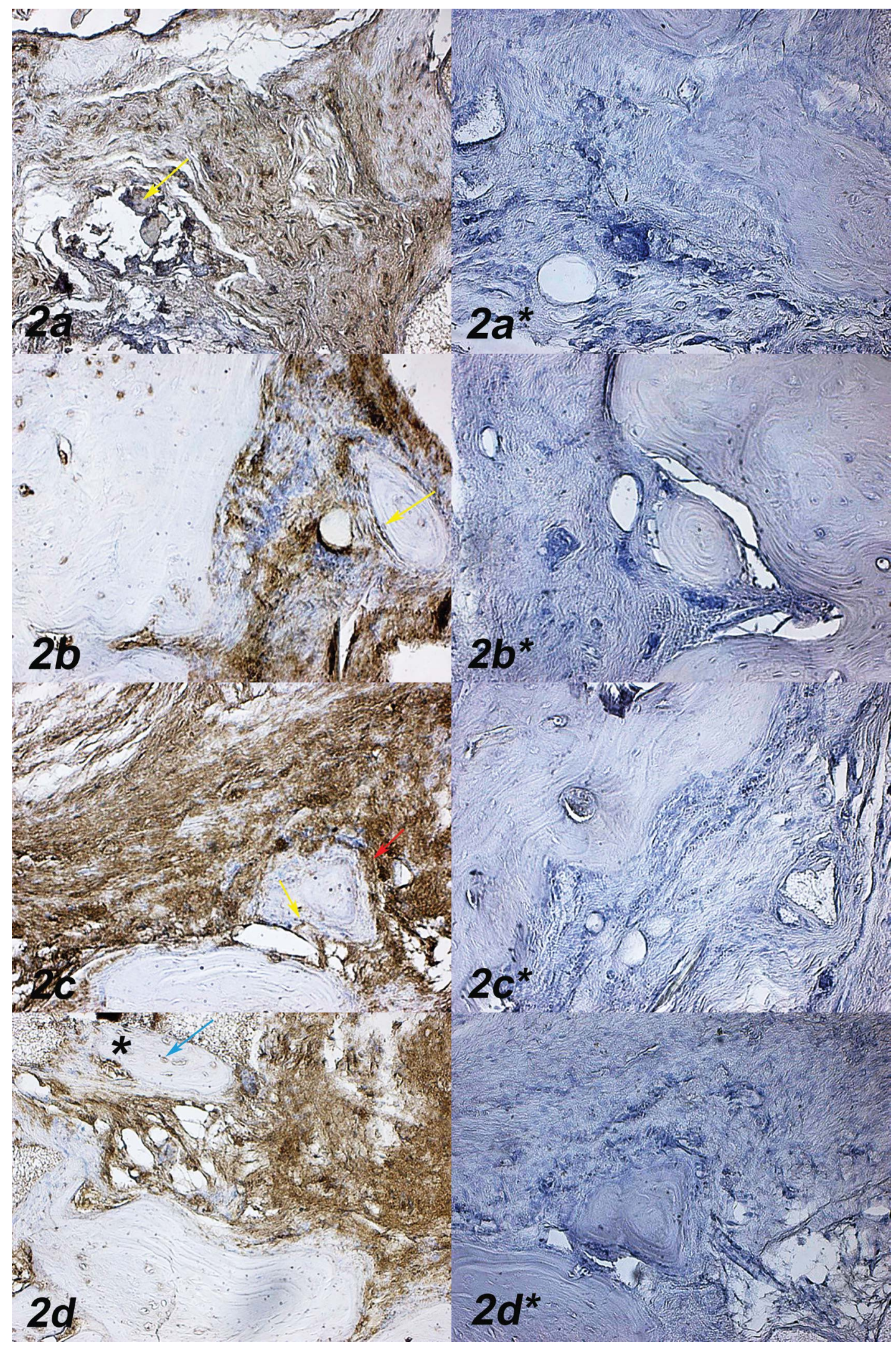

Figure 2. a. Osteopontin immunostaining, defect + ozone group ( $4^{\text {th }}$ week), scale bar $=50 \mu \mathrm{m}$; $\mathbf{a}^{*}$. Negative control group ( $4^{\text {th }}$ week); haematoxylin staining, scale bar $=50 \mu \mathrm{m} ; \mathbf{b}$. Osteopontin immunostaining, defect + ozone group ( $8^{\text {th }}$ week), scale bar $=50 \mu \mathrm{m} ; \mathbf{b}^{*}$. Negative control group ( $8^{\text {th }}$ week), haematoxylin staining, scale bar $=50 \mu \mathrm{m}$; c. Osteonectin immunostaining, defect + ozone group ( $4^{\text {th }}$ week), scale bar $=50 \mu \mathrm{m} ; \mathbf{c}^{*}$. Negative control group ( $4^{\text {th }}$ week), haematoxylin staining, scale bar $=50 \mu \mathrm{m} ; \mathbf{d}$. Osteonectin immunostaining, defect + ozone group ( $8^{\text {th }}$ week), scale bar $=50 \mu \mathrm{m} ; \mathbf{d}^{*}$. Negative control group $\left(8^{\text {th }}\right.$ week), haematoxylin staining, scale bar $=50 \mu \mathrm{m}$. 
structures, and osteonectin expression (Fig. 2d, $d^{*}$ ). The defect and graft applied group revealed a significant increase in connective tissue cells in the graft site by the $4^{\text {th }}$ week. Histologically, we found an increase in osteopontin expression of fibroblast cells (Fig. 3a, red arrow), inflammatory cells (Fig. 3a, green arrow), and osteoblast cells (Fig. 3a, yellow arrow). Small bone trabeculae were obviously seen (Fig. 3a, $a^{*}$ ). For the $8^{\text {th }}$ week, osteoblast cells (Fig. 3b, yellow arrows) close to the calvarial bone area showed the enlargement of new bone trabeculae (Fig. 3b, black star) with increased osteopontin expression (Fig. 3b, $b^{*}$ ). Osteonectin expression in osteoblast cells (Fig. 3c, yellow arrows) was positive in the graft site for the $4^{\text {th }}$ week of application (Fig. 3c, $\mathrm{c}^{*}$ ). For the $8^{\text {th }}$ week, osteonectin expression increased in osteoblasts with new bone trabeculae in the graft area. Osteonectin reacted positively in osteoblast cells (Fig. 3d, yellow arrow), osteocytes (Fig. 3d, blue arrow), osteoclast cells (Fig. 3d, red arrow), and the bone matrix (Fig. 3d, $d^{*}$ ). For the defect, graft, and ozone treated group at the end of $4^{\text {th }}$ week, osteopontin expression was observed in osteoblast cells (Fig. 4a, yellow arrow), and osteocytes were peripherally seen in new bone trabeculae (Fig. 4a, black star, Fig. 4a*). For the $8^{\text {th }}$ week, despite an increase in cells and collagen fibre structures within the graft site, osteopontin expression continued to increase. Mature bone trabeculae became evident. Osteopontin expressions were observed in Haversian canals (Fig. 4b, red arrow), osteocytes (Fig. 4b, yellow arrow), and the bone matrix (Fig. 4b, $b^{*}$ ). For the $4^{\text {th }}$ week, osteonectin expression was positive in cells between the calvarial bone and the defect area. In the connective tissue cells and fibrous structures, osteonectin was positively observed in osteocyte cells (Fig. 4c, yellow arrow) in trabeculae (Fig. 4c, $c^{\star}$ ). For the $8^{\text {th }}$ week, new bone trabeculae enlarged, and the osteoblastic activity increased in the area and started to associate with the calvarial bone region. Thus, osteonectin expression is increased, and new bone formation is accelerated. Osteonectin expression in mature bone cells (Fig. 4d, black star) showed a positive reaction (Fig. $4 d, d^{*}$ ). In addition, osteoblastic activity, osteocytic activity, osteoclastic activity, and new bone formation were statistically determined among all groups for osteonectin and osteopontin expressions at the $4^{\text {th }}$ week (Tables 1, 2 and 5; Figs. 5, 6) and the $8^{\text {th }}$ week (Tables 3,4 and 6; Figs. 7,8$)$. Osteogenesis was eventually promoted in the ozone-treated graft application by the $8^{\text {th }}$ week.

\section{Quantification of immunohistochemistry}

The quantification of osteonectin and osteopontin expression in the control, defect and ozone, defect and graft, and defect, graft, and ozone groups were performed by evaluating the osteoblastic activity, osteocytic activity, osteoclastic activity, and new bone formation at the $4^{\text {th }}$ and $8^{\text {th }}$ weeks. Results of the present study were given in Tables 1,2 and 5 and Figures 5, 6 for the $4^{\text {th }}$ week and in Tables 3, 4 and 6 and Figures 7,8 for the $8^{\text {th }}$ week.

\section{DISCUSSION}

Many clinical studies have been performed on calvarial defect models to evaluate bone regeneration related to different diseases $[11,56,58,69]$. Histological techniques have been used to demonstrate tissue damage $[2,8,17]$. On the other hand, radiological and mechanical techniques have been used for structural and functional evaluations [15, $55,62]$. Different bone graft materials are currently available for regeneration of bone defects in oral and maxillofacial surgery, such as the closure of osteotomy openings and alveolar increment $[4,6,10$, $19,52]$. Synthetic bone graft materials are available in intra-bone defects, orthognathic surgery, facial bone defects, and maxillary sinus ground $[3,10,16$, $18,31,47,49]$.

Insufficient work has been carried out to show a relationship between exposure to ozone application and calvarial defect in rats $[1,32,33,45]$. Kan et al. [32] aimed to compare the efficacy of hyperbaric oxygen and systemic ozone, used separately and in combination, on the healing of bone defects. They showed that quantitative histological assessment of calvarial bone healing showed no total ossification of the critical-size cavity in any of the groups at the end of 30 days. However, they also indicated that partial intramembranous and endochondral ossification were observed during the calvarial bone defect healing process. Their histomorphometric analysis showed more new bone formation in all experimental groups compared with the control group on days 5,15 , and 30 [32]. Similarly, the effects of systemic and topical ozone applications on alveolar bone healing after tooth extraction were investigated. In the histomorphometric analysis, they concluded that measurements of mineralised and trabecular bone and osteocyte and osteoblast surfaces did not show a statistically significant difference between the sacrificed groups at the $14^{\text {th }}$ day. They also suggested that 


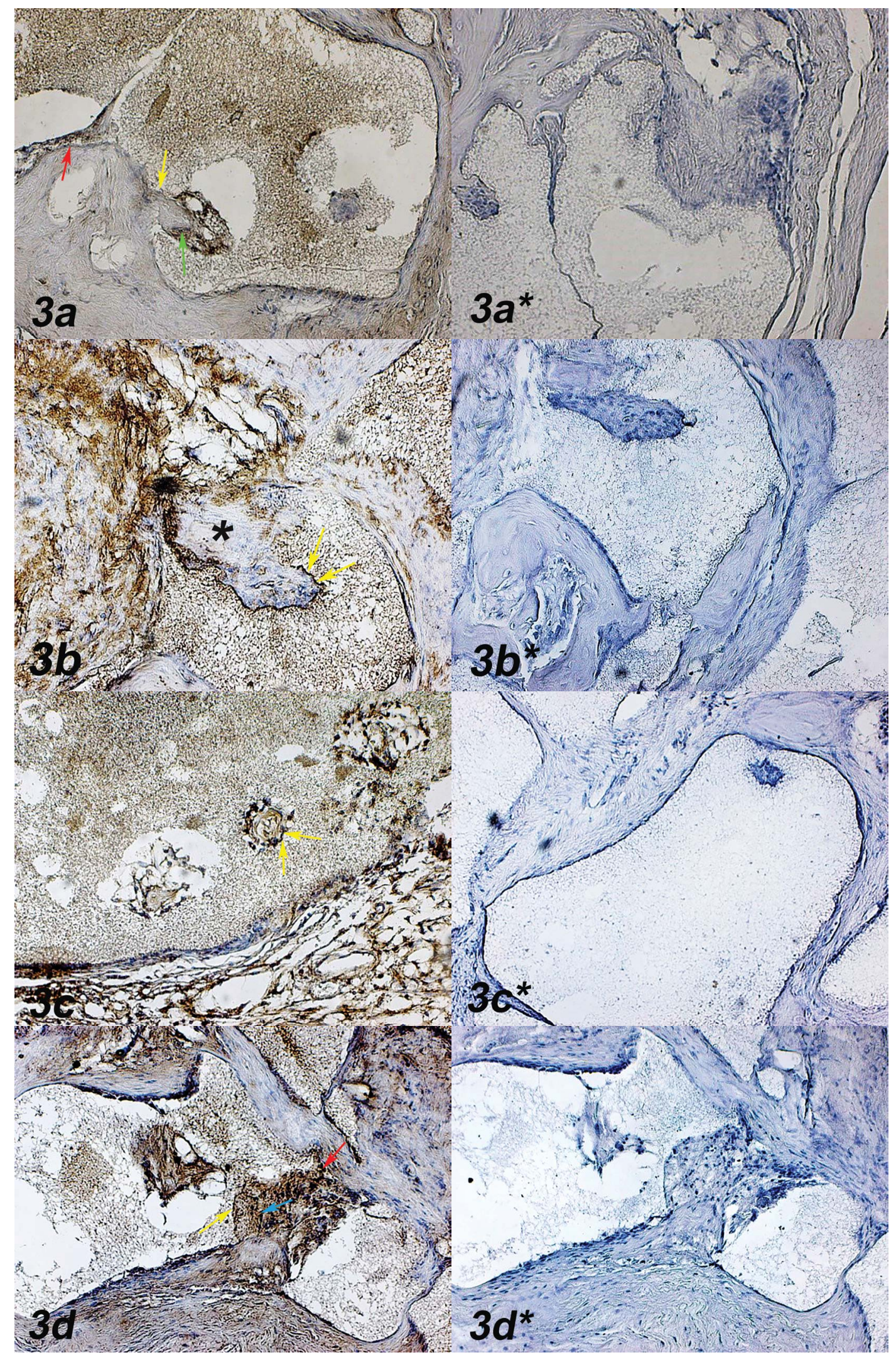

Figure 3. a. Osteopontin immunostaining, defect + graft group ( $4^{\text {th }}$ week), scale bar $=50 \mu \mathrm{m}$; $\mathbf{a}^{*}$. Negative control group ( $4^{\text {th }}$ week), haematoxylin staining, scale bar $=50 \mu \mathrm{m} ; \mathbf{b}$. Osteopontin immunostaining, defect + graft group ( $8^{\text {th }}$ week), scale bar $=50 \mu \mathrm{m} ; \mathbf{b}^{*}$. Negative control group ( $8^{\text {th }}$ week), haematoxylin staining, scale bar $=50 \mu \mathrm{m}$; c. Osteonectin immunostaining, defect + graft group ( $4^{\text {th }}$ week), scale bar $=50 \mu \mathrm{m}$; $\mathbf{c}^{*}$. Negative control group (4 $4^{\text {th }}$ week), haematoxylin staining, scale bar $=50 \mu \mathrm{m} ; \mathbf{d}$. Osteonectin immunostaining, defect + graft group ( $8^{\text {th }}$ week), scale bar $=50 \mu \mathrm{m} ; \mathbf{d}^{*}$. Negative control group $\left(8^{\text {th }}\right.$ week), haematoxylin staining, scale bar $=50 \mu \mathrm{m}$. 


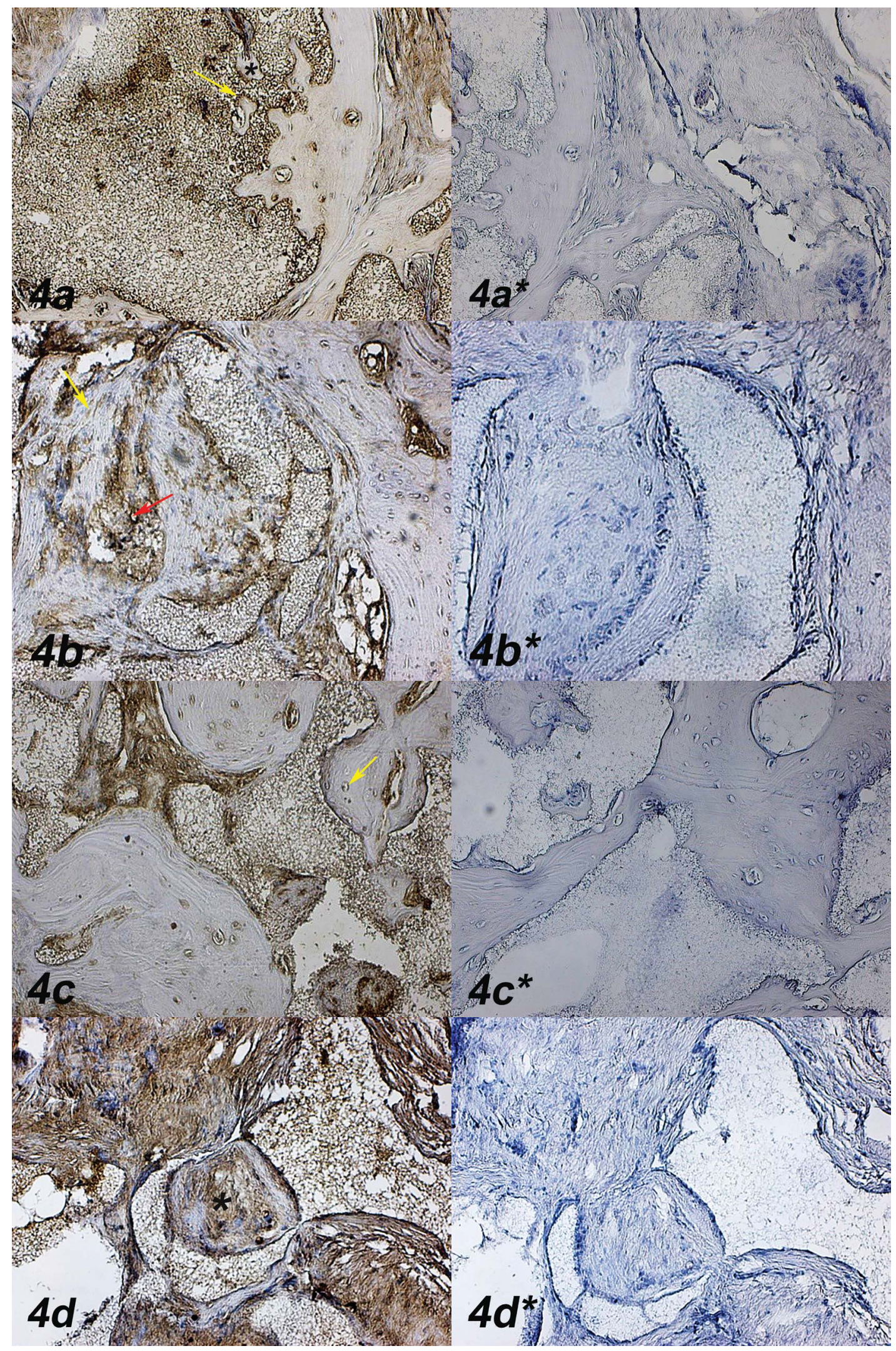

Figure 4. a. Osteopontin immunostaining, defect + graft + ozone group $\left(4^{\text {th }}\right.$ week), scale bar $=50 \mu \mathrm{m}$; $\mathbf{a}^{*}$. Negative control group ( $4^{\text {th }}$ week), haematoxylin staining, scale bar $=50 \mu \mathrm{m} ; \mathbf{b}$. Osteopontin immunostaining, defect + graft + ozone group ( $8^{\text {th }}$ week), scale bar $=50 \mu \mathrm{m}$;

$\mathbf{b}^{*}$. Negative control group ( $8^{\text {th }}$ week), haematoxylin staining, scale bar $=50 \mu \mathrm{m} ;$ c. Osteonectin immunostaining, defect + graft + ozone group $\left(4^{\text {th }}\right.$ week), scale bar $50 \mu \mathrm{m} ; \mathbf{c}^{*}$. Negative control group $\left(4^{\text {th }}\right.$ week), haematoxylin staining, scale bar $=50 \mu \mathrm{m}$; d. Osteonectin immunostaining, defect + graft + ozone group $\left(8^{\text {th }}\right.$ week), scale bar $=50 \mu \mathrm{m} ; \mathbf{4 d}^{*}$. Negative control group ( $8^{\text {th }}$ week), haematoxylin staining, scale bar $=50 \mu \mathrm{m}$. 
Table 1. Evaluation of osteonectin expression results of parameters at $4^{\text {th }}$ week by Kruskal-Wallis test ( ${ }^{*}$ statistically significant result)

\begin{tabular}{|c|c|c|c|c|}
\hline \multirow[t]{2}{*}{ Groups } & & \multicolumn{3}{|c|}{ Osteonectin expression at $4^{\text {th }}$ week } \\
\hline & & Osteoblastic activity & Osteocytic activity & Osteoclastic activity \\
\hline \multirow[t]{4}{*}{ Control group } & Minimum & 0 & 0 & 2 \\
\hline & Maximum & 1 & 1 & 4 \\
\hline & Range & 1 & 1 & 2 \\
\hline & Median & 1.00 & 0.00 & 3.00 \\
\hline \multirow[t]{4}{*}{ Defect + ozone group } & Minimum & 1 & 2 & 2 \\
\hline & Maximum & 3 & 3 & 3 \\
\hline & Range & 2 & 1 & 1 \\
\hline & Median & 2.00 & 2.00 & 2.00 \\
\hline \multirow[t]{4}{*}{ Defect + graft group } & Minimum & 1 & 2 & 2 \\
\hline & Maximum & 2 & 3 & 3 \\
\hline & Range & 1 & 1 & 1 \\
\hline & Median & 2.00 & 2.00 & 2.00 \\
\hline \multirow[t]{5}{*}{ Defect + graft + ozone group } & Minimum & 2 & 3 & 0 \\
\hline & Maximum & 3 & 4 & 2 \\
\hline & Range & 1 & 1 & 2 \\
\hline & Median & 3.00 & 3.00 & 1.00 \\
\hline & & Groups & $\mathbf{N}$ & Mean rank \\
\hline \multirow{5}{*}{\multicolumn{2}{|c|}{$\begin{array}{l}\text { Osteonectin expression at } 4^{\text {th }} \text { week } \\
\text { (Osteoblastic activity) }\end{array}$}} & Control group & 7 & 5.43 \\
\hline & & Defect + ozone group & 7 & 16.79 \\
\hline & & Defect + graft group & 7 & 12.71 \\
\hline & & Defect + graft + ozone group & 7 & 23.07 \\
\hline & & Total & 28 & \\
\hline \multirow{5}{*}{\multicolumn{2}{|c|}{$\begin{array}{l}\text { Osteonectin expression at } 4^{\text {th }} \text { week } \\
\text { (Osteocytic activity) }\end{array}$}} & Control group & 7 & 4.00 \\
\hline & & Defect + ozone group & 7 & 15.57 \\
\hline & & Defect + graft group & 7 & 15.57 \\
\hline & & Defect + graft + ozone group & 7 & 22.86 \\
\hline & & Total & 28 & \\
\hline \multirow{5}{*}{\multicolumn{2}{|c|}{$\begin{array}{l}\text { Osteonectin expression at } 4^{\text {th }} \text { week } \\
\text { (Osteoclastic activity) }\end{array}$}} & Control group & 7 & 22.50 \\
\hline & & Defect + ozone group & 7 & 14.71 \\
\hline & & Defect + graft group & 7 & 16.07 \\
\hline & & Defect + graft + ozone group & 7 & 4.71 \\
\hline & & Total & 28 & \\
\hline \multicolumn{2}{|l|}{ Osteonectin expression at $4^{\text {th }}$ week } & Osteoblastic activity & Osteocytic activity & Osteoclastic activity \\
\hline \multicolumn{2}{|l|}{ Chi-square } & 18.932 & 20.803 & 18.443 \\
\hline \multicolumn{2}{|l|}{ df } & 3 & 3 & 3 \\
\hline \multicolumn{2}{|l|}{ Asymp. Sig. } & $0.000^{*}$ & $0.000^{*}$ & $0.000^{*}$ \\
\hline
\end{tabular}

there have been no statistically significant findings in the mineralised bone and osteoblast field areas between the groups sacrificed on day 28. However, the comparison of the histomorphometric parameters of the trabecular bone between days 14 and 28 showed higher values on day 28. In addition, they observed statistically significant decreases in mineralised bone and osteocyte-osteoblast surfaces for all of the groups sacrificed on day 28 [21]. Accordingly, the effects of exposure to ozone application on calvarial defects and 
Table 2. Evaluation of osteopontin expression results of parameters at $4^{\text {th }}$ week by Kruskal-Wallis test ( ${ }^{*}$ statistically significant result)

\begin{tabular}{|c|c|c|c|c|c|}
\hline \multirow[t]{2}{*}{ Groups } & & \multicolumn{4}{|c|}{ Osteopontin expression at $4^{\text {th }}$ week } \\
\hline & & Osteoblastic activity & Osteocytic activity & Osteoclastic activity & New bone formation \\
\hline \multirow[t]{4}{*}{ Control group } & Minimum & 0 & 0 & 2 & 0 \\
\hline & Maximum & 1 & 1 & 4 & 1 \\
\hline & Range & 1 & 1 & 2 & 1 \\
\hline & Median & 1.00 & 0.00 & 3.00 & 0.00 \\
\hline \multirow[t]{4}{*}{ Defect + ozone group } & Minimum & 1 & 2 & 2 & 1 \\
\hline & Maximum & 3 & 3 & 3 & 2 \\
\hline & Range & 2 & 1 & 1 & 1 \\
\hline & Median & 2.00 & 2.00 & 2.00 & 2.00 \\
\hline \multirow[t]{4}{*}{ Defect + graft group } & Minimum & 1 & 2 & 2 & 1 \\
\hline & Maximum & 2 & 3 & 3 & 3 \\
\hline & Range & 1 & 1 & 1 & 2 \\
\hline & Median & 2.00 & 2.00 & 2.00 & 2.00 \\
\hline \multirow[t]{5}{*}{ Defect + graft + ozone group } & Minimum & 2 & 3 & 0 & 3 \\
\hline & Maximum & 3 & 4 & 2 & 4 \\
\hline & Range & 1 & 1 & 2 & 1 \\
\hline & Median & 3.00 & 3.00 & 1.00 & 3.00 \\
\hline & & \multicolumn{2}{|c|}{ Groups } & $\mathbf{N}$ & Mean rank \\
\hline \multirow{5}{*}{$\begin{array}{l}\text { Osteopontin expression at } 4^{\text {th }} \text { week } \\
\text { (Osteoblastic activity) }\end{array}$} & & \multicolumn{2}{|c|}{ Control group } & 7 & 5.43 \\
\hline & & \multicolumn{2}{|c|}{ Defect + ozone group } & 7 & 16.79 \\
\hline & & \multicolumn{2}{|c|}{ Defect + graft group } & 7 & 12.71 \\
\hline & & \multicolumn{2}{|c|}{ Defect + graft + ozone group } & 7 & 23.07 \\
\hline & & \multicolumn{2}{|c|}{ Total } & 28 & \\
\hline \multirow{5}{*}{$\begin{array}{l}\text { Osteopontin expression at } 4^{\text {th }} \text { week } \\
\text { (Osteocytic activity) }\end{array}$} & & \multicolumn{2}{|c|}{ Control group } & 7 & 4.00 \\
\hline & & \multicolumn{2}{|c|}{ Defect + ozone group } & 7 & 15.57 \\
\hline & & \multicolumn{2}{|c|}{ Defect + graft group } & 7 & 15.57 \\
\hline & & \multicolumn{2}{|c|}{ Defect + graft + ozone group } & 7 & 22.86 \\
\hline & & \multicolumn{2}{|c|}{ Total } & 28 & \\
\hline \multirow{5}{*}{$\begin{array}{l}\text { Osteopontin expression at } 4^{\text {th }} \text { week } \\
\text { (Osteoclastic activity) }\end{array}$} & & \multicolumn{2}{|c|}{ Control group } & 7 & 22.50 \\
\hline & & \multicolumn{2}{|c|}{ Defect + ozone group } & 7 & 14.71 \\
\hline & & \multicolumn{2}{|c|}{ Defect + graft group } & 7 & 16.07 \\
\hline & & \multicolumn{2}{|c|}{ Defect + graft + ozone group } & 7 & 4.71 \\
\hline & & \multicolumn{2}{|c|}{ Total } & 28 & \\
\hline Osteopontin expression at $4^{\text {th }}$ week & & Contro & roup & 7 & 4.21 \\
\hline (New bone formation) & & Defect $+c$ & ne group & 7 & 12.79 \\
\hline & & Defect + & aft group & 7 & 16.86 \\
\hline & & Defect + graft & ozone group & 7 & 24.14 \\
\hline & & & & 28 & \\
\hline Osteopontin expression at $4^{\text {th }}$ week & & Osteoblastic activity & Osteocytic activity & Osteoclastic activity & New bone formation \\
\hline Chi-square & & 18.932 & 20.803 & 18.443 & 22.612 \\
\hline$d f$ & & 3 & 3 & 3 & 3 \\
\hline Asymp. Sig. & & $0.000^{*}$ & $0.000^{*}$ & $0.000^{*}$ & $0.000^{*}$ \\
\hline
\end{tabular}


Table 3. Evaluation of osteonectin expression results of parameters at $8^{\text {th }}$ week by Kruskal-Wallis test ( ${ }^{*}$ statistically significant result)

\begin{tabular}{|c|c|c|c|c|}
\hline \multirow[t]{2}{*}{ Groups } & & \multicolumn{3}{|c|}{ Osteonectin expression at 8th week } \\
\hline & & Osteoblastic activity & Osteocytic activity & Osteoclastic activity \\
\hline \multirow[t]{4}{*}{ Control group } & Minimum & 1 & 0 & 0 \\
\hline & Maximum & 2 & 2 & 2 \\
\hline & Range & 1 & 2 & 2 \\
\hline & Median & 2.00 & 1.00 & 1.00 \\
\hline \multirow[t]{4}{*}{ Defect + ozone group } & Minimum & 2 & 2 & 0 \\
\hline & Maximum & 3 & 4 & 1 \\
\hline & Range & 1 & 2 & 1 \\
\hline & Median & 3.00 & 3.00 & 1.00 \\
\hline \multirow[t]{4}{*}{ Defect + graft group } & Minimum & 2 & 2 & 1 \\
\hline & Maximum & 3 & 4 & 2 \\
\hline & Range & 1 & 2 & 1 \\
\hline & Median & 2.00 & 3.00 & 1.00 \\
\hline \multirow[t]{5}{*}{ Defect + graft + ozone group } & Minimum & 3 & 3 & 0 \\
\hline & Maximum & 4 & 4 & 1 \\
\hline & Range & 1 & 1 & 1 \\
\hline & Median & 4.00 & 4.00 & .00 \\
\hline & & Groups & $\mathbf{N}$ & Mean rank \\
\hline \multirow{5}{*}{\multicolumn{2}{|c|}{$\begin{array}{l}\text { Osteonectin expression at } 8^{\text {th }} \text { week } \\
\text { (Osteoblastic activity) }\end{array}$}} & Control group & 7 & 5.71 \\
\hline & & Defect + ozone group & 7 & 16.00 \\
\hline & & Defect + graft group & 7 & 13.00 \\
\hline & & Defect + graft + ozone group & 7 & 23.29 \\
\hline & & Total & 28 & \\
\hline \multirow{5}{*}{\multicolumn{2}{|c|}{$\begin{array}{l}\text { Osteonectin expression at } 8^{\text {th }} \text { week } \\
\text { (Osteocytic activity) }\end{array}$}} & Control group & 7 & 4.43 \\
\hline & & Defect + ozone group & 7 & 15.86 \\
\hline & & Defect + graft group & 7 & 14.79 \\
\hline & & Defect + graft + ozone group & 7 & 22.93 \\
\hline & & Total & 28 & \\
\hline \multirow{5}{*}{\multicolumn{2}{|c|}{$\begin{array}{l}\text { Osteonectin expression at } 8^{\text {th }} \text { week } \\
\text { (Osteoclastic activity) }\end{array}$}} & Control group & 7 & 18.00 \\
\hline & & Defect + ozone group & 7 & 11.86 \\
\hline & & Defect + graft group & 7 & 19.71 \\
\hline & & Defect + graft + ozone group & 7 & 8.43 \\
\hline & & Total & 28 & \\
\hline \multicolumn{2}{|l|}{ Osteonectin expression at $8^{\text {th }}$ week } & Osteoblastic activity & Osteocytic activity & Osteoclastic activity \\
\hline \multicolumn{2}{|l|}{ Chi-square } & 18.450 & 19.208 & 10.621 \\
\hline \multicolumn{2}{|l|}{ df } & 3 & 3 & 3 \\
\hline \multicolumn{2}{|l|}{ Asymp. Sig. } & $0.000^{*}$ & $0.000^{*}$ & $0.014^{*}$ \\
\hline
\end{tabular}

their healing time are not well known. However, it is well known that ozone accelerates wound healing and increases blood flow. It is dissolved in water or gas for medical purposes. Exposure to ozone application can induce several biological responses, such as improving blood circulation and accelerated oxygen capacity in ischaemic tissue, upregulating cellular antioxidant enzymes, facilitating the activation of the immune system, and supporting the secretion of growth factors [57]. 
Table 4. Evaluation of osteopontin expression results of parameters at $8^{\text {th }}$ week by Kruskal-Wallis test ( ${ }^{*}$ statistically significant result)

\begin{tabular}{|c|c|c|c|c|c|}
\hline \multirow[t]{2}{*}{ Groups } & & \multicolumn{4}{|c|}{ Osteopontin expression at $8^{\text {th }}$ week } \\
\hline & & Osteoblastic activity & Osteocytic activity & Osteoclastic activity & New bone formation \\
\hline \multirow[t]{4}{*}{ Control group } & Minimum & 2 & 1 & 1 & 1 \\
\hline & Maximum & 3 & 3 & 3 & 3 \\
\hline & Range & 1 & 2 & 2 & 2 \\
\hline & Median & 3.00 & 2.00 & 2.00 & 2.00 \\
\hline \multirow[t]{4}{*}{ Defect + ozone group } & Minimum & 2 & 2 & 0 & 3 \\
\hline & Maximum & 4 & 4 & 1 & 4 \\
\hline & Range & 2 & 2 & 1 & 1 \\
\hline & Median & 3.00 & 3.00 & 0.00 & 4.00 \\
\hline \multirow[t]{4}{*}{ Defect + graft group } & Minimum & 1 & 2 & 0 & 3 \\
\hline & Maximum & 3 & 4 & 2 & 4 \\
\hline & Range & 2 & 2 & 2 & 1 \\
\hline & Median & 2.00 & 3.00 & 1.00 & 3.00 \\
\hline \multirow[t]{5}{*}{ Defect + graft + ozone group } & Minimum & 3 & 3 & 0 & 3 \\
\hline & Maximum & 4 & 4 & 1 & 4 \\
\hline & Range & 1 & 1 & 1 & 1 \\
\hline & Median & 4.00 & 4.00 & 0.00 & 4.00 \\
\hline & & \multicolumn{2}{|c|}{ Groups } & $\mathbf{N}$ & Mean rank \\
\hline \multirow{5}{*}{$\begin{array}{l}\text { Osteopontin expression at } 8^{\text {th }} \text { week } \\
\text { (Osteoblastic activity) }\end{array}$} & & \multicolumn{2}{|c|}{ Control group } & 7 & 12.29 \\
\hline & & \multicolumn{2}{|c|}{ Defect + ozone group } & 7 & 16.50 \\
\hline & & \multicolumn{2}{|c|}{ Defect + graft group } & 7 & 7.07 \\
\hline & & \multicolumn{2}{|c|}{ Defect + graft + ozone group } & 7 & 22.14 \\
\hline & & \multicolumn{2}{|c|}{ Total } & 28 & \\
\hline \multirow{5}{*}{$\begin{array}{l}\text { Osteopontin expression at } 8^{\text {th }} \text { week } \\
\text { (Osteocytic activity) }\end{array}$} & & \multicolumn{2}{|c|}{ Control group } & 7 & 8.50 \\
\hline & & \multicolumn{2}{|c|}{ Defect + ozone group } & 7 & 16.00 \\
\hline & & \multicolumn{2}{|c|}{ Defect + graft group } & 7 & 11.86 \\
\hline & & \multicolumn{2}{|c|}{ Defect + graft + ozone group } & 7 & 21.64 \\
\hline & & \multicolumn{2}{|c|}{ Total } & 28 & \\
\hline \multirow{5}{*}{$\begin{array}{l}\text { Osteopontin expression at } 8^{\text {th }} \text { week } \\
\text { (Osteoclastic activity) }\end{array}$} & & \multicolumn{2}{|c|}{ Control group } & 7 & 23.93 \\
\hline & & \multicolumn{2}{|c|}{ Defect + ozone group } & 7 & 10.50 \\
\hline & & \multicolumn{2}{|c|}{ Defect + graft group } & 7 & 14.57 \\
\hline & & \multicolumn{2}{|c|}{ Defect + graft + ozone group } & 7 & 9.00 \\
\hline & & \multicolumn{2}{|c|}{ Total } & 28 & \\
\hline Osteopontin expression at $8^{\text {th }}$ week & & Contro & group & 7 & 5.29 \\
\hline & & Defect $+c$ & one group & 7 & 17.57 \\
\hline & & Defect + & aft group & 7 & 14.29 \\
\hline & & Defect + graft & ozone group & 7 & 20.86 \\
\hline & & & & 28 & \\
\hline Osteopontin expression at $8^{\text {th }}$ week & & Osteoblastic activity & Osteocytic activity & Osteoclastic activity & New bone formation \\
\hline Chi-square & & 14.479 & 11.272 & 15.729 & 16.237 \\
\hline df & & 3 & 3 & 3 & 3 \\
\hline Asymp. Sig. & & 0.002 & 0.010 & 0.001 & 0.001 \\
\hline
\end{tabular}


Table 5. Comparison of osteonectin and osteopontin expressions at the $4^{\text {th }}$ week as a binary group with the Bonferroni correction Mann-Whitney $U$ test $\left({ }^{*} p<0.05\right.$ is statistically significant result by Bonferroni correction Mann-Whitney $U$ test)

\section{Osteonectin expressio}

1-2

1-3

1-4

2-3

2-4

3-4

Osteocytic activity

1-2

1-3

1-4

2-3

2-4

3-4

Osteoclastic activity

1-2

1-3

1-4

2-3

2-4

3-4

Osteoblastic activity

1-2

1-3
$P$ value

$0.038<0.05^{*}$

$0.481>0.05$

$0.000<0.05^{*}$

$1.000>0.05$

$0.077>0.05$

$0.787>0.05$

$0.034<0.05^{*}$

$0.034<0.05^{*}$

$0.000<0.05^{*}$

$1.000>0.05$

$0.491>0.05$

$0.491>0.05$

$0.381>0.05$

$0.752>0.05$

$0.000<0.05^{*}$

$1.000>0.05$

$0.103>0.05$

$0.007<0.05 *$

$0.0038<0.05^{*}$

$0.481>0.05$

\begin{tabular}{l}
\hline Osteonectin expression \\
\hline $1-4$ \\
$2-3$ \\
$2-4$ \\
$3-4$ \\
0steocytic activity \\
$1-2$ \\
$1-3$ \\
$1-4$ \\
$2-3$ \\
$2-4$ \\
$3-4$
\end{tabular}

\section{Osteoclastic activity}

$$
\text { 1-2 }
$$

1-3

1-4

2-3

2-4

3-4

\section{New bone formation}

1-2

$0.272>0.05$

1-3

1-4

$0.019<0.05^{*}$

$0.000<0.05^{*}$

2-3

$1.000>0.05$

2-4

$0.048<0.05^{*}$

3-4

$0.533>0.05$

1 - control group; 2 - defect + ozone group; 3 - defect + graft group; $4-$ defect + graft + ozone group

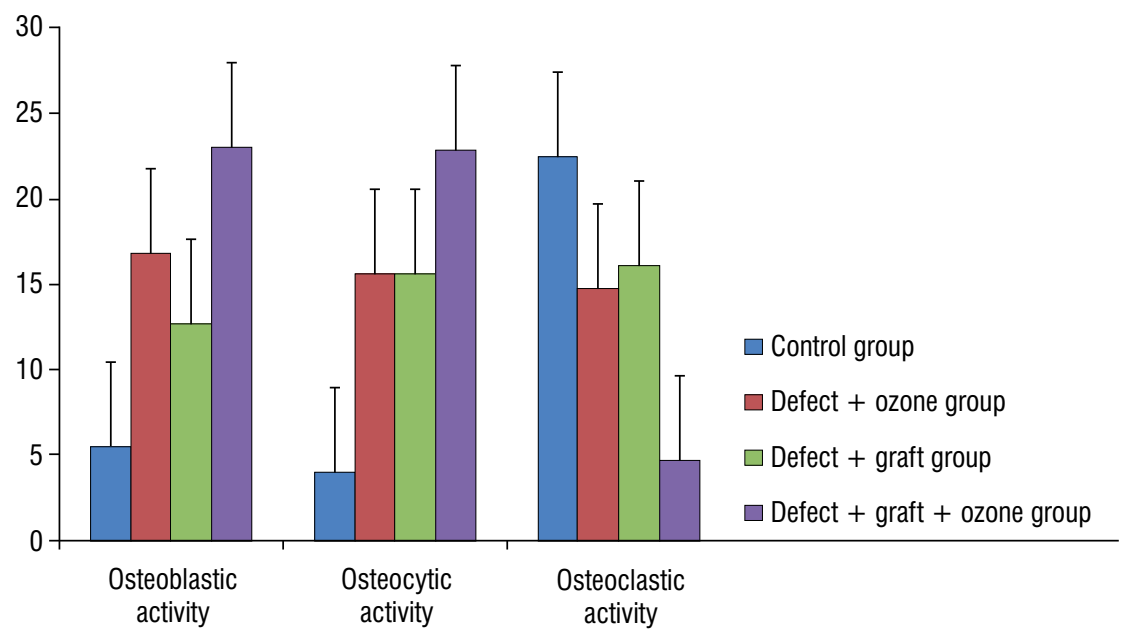

Figure 5. Graphic showing the evaluation of osteonectin expression results for parameters at the $4^{\text {th }}$ week in the control and experimental groups. 


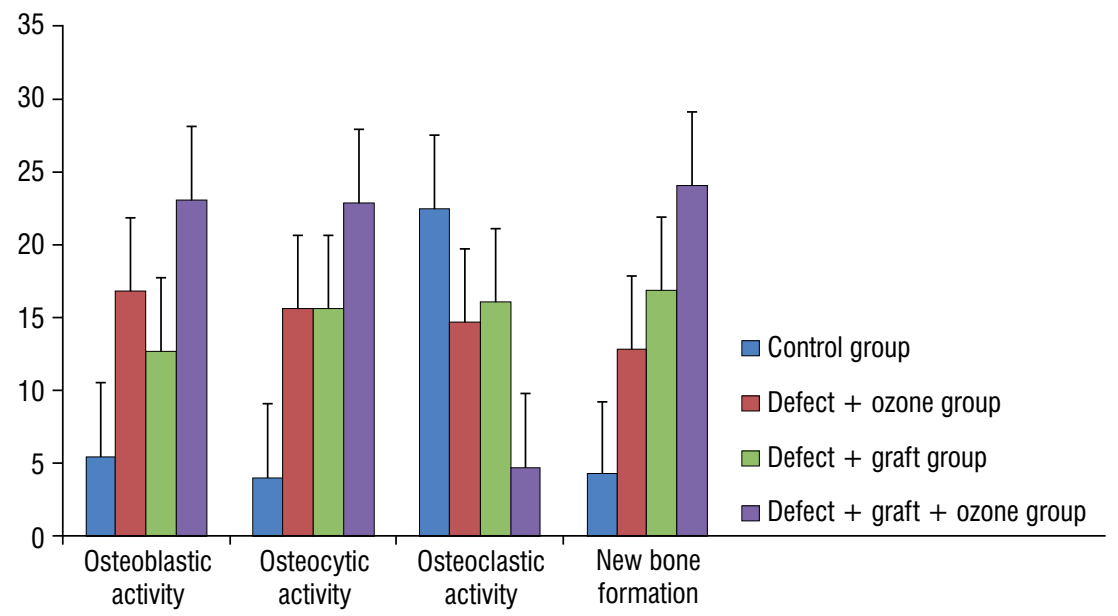

Figure 6. Graphic showing the evaluation of osteopontin expression results for parameters at the $4^{\text {th }}$ week in the control and experimental groups.

Table 6. Comparison of osteonectin and osteopontin expressions at the $8^{\text {th }}$ week as a binary group with the Bonferroni correction Mann-Whitney $U$ test $\left({ }^{*} p<0.05\right.$ is statistically significant result by Bonferroni correction Mann-Whitney $U$ test)

\section{Osteonectin express}

$1-2$

1-3

$1-4$

2-3

2-4

3-4

\section{Osteocytic activity}

1-2

1-3

1-4

2-3

2-4

3-4

Osteoclastic activity

1-2

1-3

1-4

2-3

2-4

3-4

Osteoblastic activity

1-2

1-3

\begin{tabular}{l}
\hline 0st \\
\hline $1-4$ \\
$2-3$ \\
$2-4$ \\
$3-4$ \\
$0 s$ \\
$1-2$ \\
$1-3$ \\
$1-4$ \\
$2-3$ \\
$2-4$ \\
$3-4$
\end{tabular}

\section{Osteoclastic activity}

$$
1-2
$$$$
\text { 1-3 }
$$

$0.090>0.05$

$0.000<0.05^{*}$

$1.000>0.05$

$0.336>0.05$

$0.582>0.05$

$0.725>0.05$

$1.000>0.05$

$0.094>0.05$

$0.283>0.05$

$1.000>0.05$

$0.026<0.05^{*}$

$1.000>0.05$

$1.000>0.05$ 


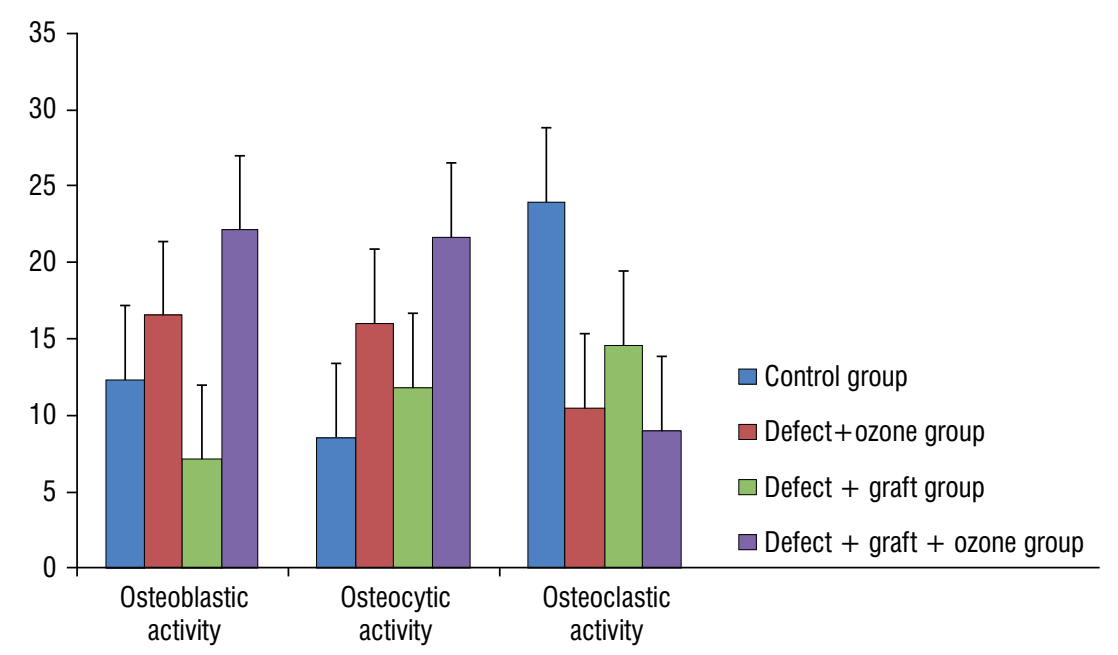

Figure 7. Graphic showing the evaluation of osteonectin expression results for parameters at the $8^{\text {th }}$ week in the control and experimental groups.

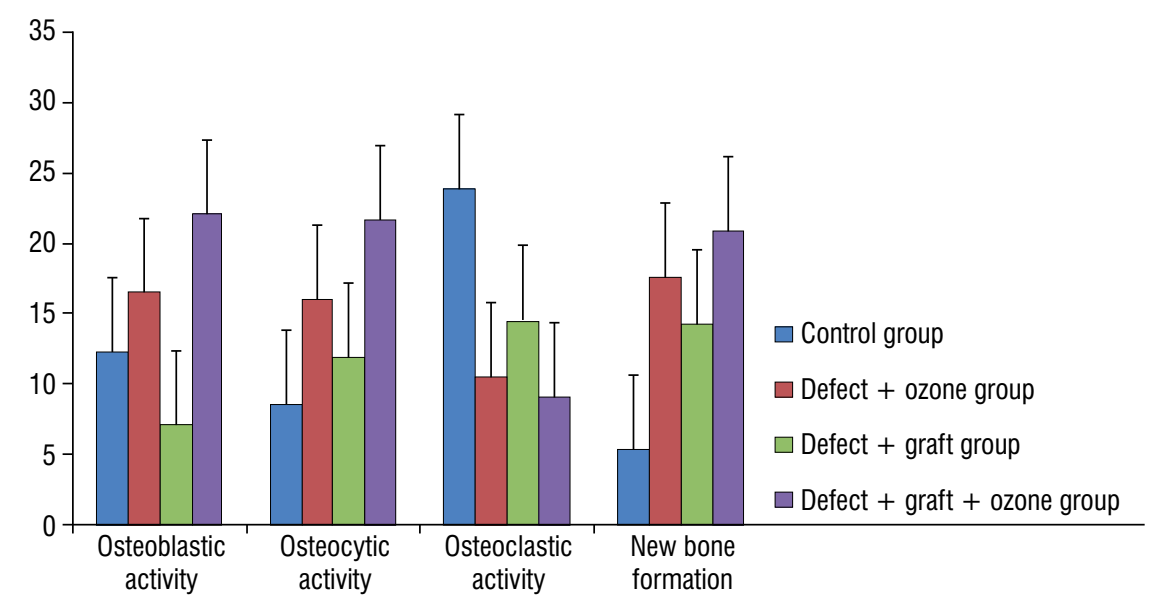

Figure 8. Graphic showing the evaluation of osteopontin expression results for parameters at the $8^{\text {th }}$ week in the control and experimental groups.

Alpan et al. [1] suggested that treatment with ozone supports the consistency of xenograft and promotes regeneration of bone on a model of a calvarial defect in diabetic rats. In an experimental study, they asserted that both hyperbaric oxygen and ozone depicted the same efficacy to augment bone healing and that the concomitant use of them would be more effective [32]. Laçin et al. [39] confirmed that ozone has healing effects on bone defects at 4- and 8-week intervals, indicating that graft and ozone application is the best practice for new bone formation. They emphasised that ozone treatment establishes homeostasis by supporting angiogenesis and cell proliferation and induces the synthesis of a group of cytokines, such as leukotrienes, interleukins, and prostaglandins. Ozone treatment triggers macrophage activation and expedites phagocytosis. It also has a definite effect on bone formation compared to the controls in the calvarial defect rate model [33]. Ozdemir et al. [45] investigated the effect of exposure to ozone application on autogenous bone graft healing in calvarial defects. The authors indicated that ozone treatment increased the formation of fresh bone with the application of an autogenous bone graft in the calvarial defect rat model. Histomorphometrically, they observed that the total bone area in the autogenous bone graft with exposure to ozone application group was significantly higher than that of the autogenous bone graft group. They also supported that the exposure to the ozone application group significantly increased the percentage of total bone area, osteoblast numbers, and new bone formation compared to the autogenous bone graft group. In another study, alternative ozone thera- 
pies on bone regeneration were investigated in the inter-premaxillary suture expansion on rats. Ozone treatment expedited the acceleration in the formation of fresh calcified bone in the area of suture [9].

Osteopontin promotes the early differentiation of osteoblasts, their adhesion to the bone, and bone formation. Bone cells secrete osteopontin during the process of bone remodelling and increase osteopontin expression in response to mechanical stimuli $[14,37]$. Choi et al. [14] proposed that patients with ankylosing spondylitis with had significantly higher plasma osteopontin, tumour necrosis factor-alpha, and interleukin- 6 levels and more mRNA expression than healthy controls. Klein-Nulend et al. [37] suggested that osteopontin appeared to stimulate adhesion, migration, and bone resorption by osteoclasts. They found that severe loss of osteopontin expression in primary bone cells cultured without mechanical stimulation down-regulated conditions of use to differentiate the osteoblastic phenotype [37]. To understand the interplay between systemic and local signalling in bone, they examined the effects of deficiency of the bone matrix protein osteopontin on the systemic effects of the parathyroid hormone, specifically within osteoblastic cell lineages. Parathyroid hormone receptor (PPR) in transgenic mice expressing a constitutively active form of the receptor (caPPR), specifically in cells of the osteoblast lineage, has a high bone mass phenotype. In these mice, osteopontin deficiency further increased bone mass. They indicated that this increase was associated with the conversion of the major intertrabecular cell population from haematopoietic cells to stromal/osteoblastic cells and with parallel elevations in the histomorphometric and biochemical parameters of bone formation and resorption [43]. Ihara et al. [29] aimed to obtain insight into the cellular mechanism underlying the phenomena observed in the osteopontin-deficient bone. They investigated the number of tartrate-resistant acid phosphatase (TRAP)-positive cells in the bones subjected to parathyroid hormone treatment in cultures. They found that the number of TRAP-positive cells increased significantly by parathyroid hormone in wild type bone; however, no such parathyroid hormone-induced increase in the TRAP-positive cells was observed in osteopontin-deficient bones. Their results indicated that the absence of osteopontin suppressed the parathyroid hormone-induced increase in bone resorption by preventing the increase in the number of osteoclasts in the local milieu of bone [29]. Kho- jasteh et al. [35] compared culture-expanded bone marrow-derived mesenchymal stem cells and platelet-rich plasma loaded to natural bone mineral (biooss) and beta-tricalcium phosphate for rat calvarial bone repair. According to their immunohistochemical observation, they concluded that the positive immunoreaction for osteopontin and osteonectin was significant in all groups. Based on these positive expressions in the defect area, they concluded that bone formation and mineralisation proceeded from the defect border to the centre [35]. Double administration of platelet-rich plasma has been reported to have no additional benefits for osteonectin and osteocalcin expression levels during bone healing in a rabbit cranial defect model. Furthermore, the findings revealed that the presence of beta-tricalcium phosphate affects osteonectin and osteocalcin expressions, suggesting the potential for beta-tricalcium phosphate to support early bone healing [44].

\section{Limitations of the study}

Despite the results, there are a few limitations in clinical contribution. Very few experimental studies exist on the use of alloplastic graft material with ozone application. Graft materials are used to prevent damage to the bones caused by defects in patients, inducing osteoblastic activity in bone repair and stimulating osteocyte and trabecular bone development. Whereas graft application has a stimulating and curative effect on bone tissue, the use of ozone is thought to induce alloplastic graft application by accelerating calvarial bone development in rats.

\section{CONCLUSIONS}

In our study, the group with 4 weeks of ozone application revealed a positive reaction in osteoclast cells and osteopontin expression in inflammatory cells. Osteoblastic activity began to increase within the defect area at the $8^{\text {th }}$ week, and osteopontin expression reacted positively in the osteoblasts and bone matrix.

At the end of the $4^{\text {th }}$ week in the defect and ozone group, fibroblast osteoclasts in the defect area and osteopontin expression in the inflammatory cells reacted positively. At week 8 , new bone trabeculae were formed, osteoblastic activity increased, and osteopontin expression in osteoblast cells became evident. In the immunohistochemical examination of the defect and ozone group, an increase in the connective tissue between the defect area and the calvarial bone was observed (Fig. 2c, $c^{*}$ ). Osteonectin 
was accelerated in fibroblasts and osteoblasts. In the $8^{\text {th }}$ week, fibroblast macrophages and positive osteonectin expression in osteoblast cells were observed, but new bone trabeculae, osteocytes, and osteon structures became evident (Fig. 2d, $d^{*}$ ).

Positive expression was observed in the osteoblast cells at the graft site at the $4^{\text {th }}$ week in the sections of the defect and graft group (Fig. 3c), whereas osteoblast cells with new bone trabeculae and bone matrix showed an increased expression of osteoblast cells at the $8^{\text {th }}$ week (Fig. $3 d, d^{*}$ ).

In the defect, graft, and ozone group ( $4^{\text {th }}$ week), osteopontin expression was positive in osteoblast osteocytes, whereas new bone was visible in the trabeculae. At the $8^{\text {th }}$ week, mature bone trabeculae developed Haversian ducts and increased osteopontin expression in osteocytes. In addition, we observed the positive expression of osteonectin in fibroblasts and some osteoblasts in the control group ( $4^{\text {th }}$ week; Fig. 1c, $\left.c^{\star}\right)$. The defect, graft, and ozone application resulted in new bone trabeculae at the $4^{\text {th }}$ week (Fig. 4c, $\mathrm{C}^{\star}$ ). Osteoblast cells showed positive osteonectin expression, and in 8 weeks, the osteon tissues and osteocytes reacted positively (Fig. 4d, $d^{*}$ ). Exposure to ozone application is used in combination with grafts in rat calvarial defects, and mature bone structure develops after about 8 weeks of bone matrix formation and new bone remodelling.

In the control group, osteonectin expression in the osteoblast cells and bone matrix increased in new bone trabeculae at the $8^{\text {th }}$ week (Fig. 1d, $d^{*}$ ).

\section{REFERENCES}

1. Alpan AL, Toker H, Ozer H. Ozone therapy enhances osseous healing in rats with diabetes with calvarial defects: a morphometric and immunohistochemical study. J Periodontol. 2016; 87(8): 982-989, doi: 10.1902/ jop.2016.160009, indexed in Pubmed: 26991488.

2. An YZ, Heo YK, Lee JS, et al. Dehydrothermally cross-linked collagen membrane with a bone graft improves bone regeneration in a rat calvarial defect model. Materials (Basel). 2017; 10(8), doi: 10.3390/ma10080927, indexed in Pubmed: 28796152.

3. Ardeshirylajimi A, Farhadian S, Adegani FJ, et al. Enhanced osteoconductivity of polyethersulphone nanofibres loaded with bioactive glass nanoparticles in in vitro and in vivo models. Cell Prolif. 2015; 48(4): 455-464, doi: 10.1111/ cpr.12198, indexed in Pubmed: 26121911.

4. Artas G, Gul M, Acikan I, et al. A comparison of different bone graft materials in peri-implant guided bone regeneration. Braz Oral Res. 2018; 32: e59, doi: 10.1590/18073107bor-2018.vol32.0059, indexed in Pubmed: 29995064.

5. Bayer S, Kazancioglu HO, Acar AH, et al. Comparison of laser and ozone treatments on oral mucositis in an experimental model. Lasers Med Sci. 2017; 32(3): 673-677, doi: 10.1007/ s10103-017-2166-1, indexed in Pubmed: 28190112.

6. Beirne OR. Comparison of complications after bone removal from lateral and medial plates of the anterior ileum for mandibular augmentation. Int J Oral Maxillofac Surg. 1986; 15(3): 269-272, doi: 10.1016/s03009785(86)80084-9.

7. Bodde EWH, Spauwen PHM, Mikos AG, et al. Closing capacity of segmental radius defects in rabbits. J Biomed Mater Res A. 2008; 85(1): 206-217, doi: 10.1002/ jbm.a.31549, indexed in Pubmed: 17688264.

8. Buffoli B, Favero G, Borsani E, et al. Sodium-DNA for bone tissue regeneration: an experimental study in rat calvaria. Biomed Res Int. 2017; 2017: 7320953, doi: 10.1155/2017/7320953, indexed in Pubmed: 29082254.

9. Buyuk SK, Ramoglu SI, Sonmez MF. The effect of different concentrations of topical ozone administration on bone formation in orthopedically expanded suture in rats. Eur J Orthod. 2016; 38(3): 281-285, doi: 10.1093/ejo/cjv045, indexed in Pubmed: 26136437.

10. Byrd HS, Hobar PC, Shewmake K. Augmentation of the craniofacial skeleton with porous hydroxyapatite granules. Plast Reconstr Surg. 1993; 91(1): 15-22; discussion 23, indexed in Pubmed: 8380106.

11. Caliaperoumal G, Souyet M, Bensidhoum M, et al. Type 2 diabetes impairs angiogenesis and osteogenesis in calvarial defects: MicroCT study in ZDF rats. Bone. 2018; 112: 161-172, doi: 10.1016/j.bone.2018.04.009, indexed in Pubmed: 29702250.

12. Cancedda R, Giannoni P, Mastrogiacomo M. A tissue engineering approach to bone repair in large animal models and in clinical practice. Biomaterials. 2007; 28(29): 4240-4250, doi: 10.1016/j.biomaterials.2007.06.023, indexed in Pubmed: 17644173.

13. Cestari TM, Granjeiro JM, de Assis GF, et al. Bone repair and augmentation using block of sintered bovine-derived anorganic bone graft in cranial bone defect model. Clin Oral Implants Res. 2009; 20(4): 340-350, doi: 10.1111/j.16000501.2008.01659.x, indexed in Pubmed: 19298288.

14. Choi ST, Kim JH, Kang EJ, et al. Osteopontin might be involved in bone remodelling rather than in inflammation in ankylosing spondylitis. Rheumatology (Oxford). 2008; 47(12): 1775-1779, doi: 10.1093/rheumatology/ken385, indexed in Pubmed: 18854347.

15. Chou J, Komuro M, Hao J, et al. Bioresorbable zinc hydroxyapatite guided bone regeneration membrane for bone regeneration. Clin Oral Implants Res. 2016; 27(3): 354-360, doi: 10.1111/clr.12520, indexed in Pubmed: 25363210.

16. Corsair A. A clinical evaluation of resorbable hydroxylapatite for the repair of human intra-osseous defects. J Oral Implantol. 1990; 16(2): 125-128, indexed in Pubmed: 1963642.

17. Deng Y, Guo T, Li J, et al. Repair of calvarial bone defect using jarid1a-knockdown bone mesenchymal stem cells in rats. Tissue Eng Part A. 2018; 24(9-10): 711-718, doi: 10.1089/ ten.tea.2017.0168, indexed in Pubmed: 28903624.

18. Diker N, Gulsever S, Koroglu T, et al. Effects of hyaluronic acid and hydroxyapatite/beta-tricalcium phosphate in combination on bone regeneration of a critical-size defect in an experimental model. J Craniofac Surg. 2018; 29(4): 1087-1093, doi: 10.1097/SCS.0000000000004338, indexed in Pubmed: 29438204. 
19. Dova S, Karkos PD, Constantinidis J. Reconstruction of frontal defects with calvarial grafts. Rhinology. 2018; 56(3): 297-302, doi: 10.4193/Rhin17.185, indexed in Pubmed: 29561919.

20. Duman I, Davul S, Gokce H, et al. Effects of gaseous ozone treatment on bone regeneration in femoral defect model in rats. J Hard Tissue Biol. 2017; 26(1): 7-12, doi: 10.2485/ jhtb.26.7.

21. Erdemci F, Gunaydin $Y$, Sencimen M, et al. Histomorphometric evaluation of the effect of systemic and topical ozone on alveolar bone healing following tooth extraction in rats. Int J Oral Maxillofac Surg. 2014; 43(6): 777-783, doi: 10.1016/j. ijom.2013.12.007, indexed in Pubmed: 24491848.

22. Erdmann N, Bondarenko A, Hewicker-Trautwein M, et al. Evaluation of the soft tissue biocompatibility of $\mathrm{MgCaO} .8$ and surgical steel $316 \mathrm{~L}$ in vivo: a comparative study in rabbits. Biomed Eng Online. 2010; 9: 63, doi: 10.1186/1475925X-9-63, indexed in Pubmed: 20974008.

23. Ferland CE, Laverty $S$, Beaudry F, et al. Gait analysis and pain response of two rodent models of osteoarthritis. Pharmacol Biochem Behav. 2011; 97(3): 603-610, doi: 10.1016/j. pbb.2010.11.003, indexed in Pubmed: 21111752.

24. Ferrari JD, Bach BR. Bone graft procurement for patellar defect grafting in anterior cruciate ligament reconstruction. Arthroscopy. 1998; 14(5): 543-545, doi: 10.1016/ s0749-8063(98)70089-1.

25. Fujishiro T, Bauer TW, Kobayashi N, et al. Histological evaluation of an impacted bone graft substitute composed of a combination of mineralized and demineralized allograft in a sheep vertebral bone defect. J Biomed Mater Res A. 2007; 82(3): 538-544, doi: 10.1002/jbm.a.31056, indexed in Pubmed: 17309059.

26. Garg AK. Grafting Materials in Repair and Restoration. In: Lynch SE, Genco RJ, Marx RE (ed. Tissue Engineering: Applications in Maxillofacial Surgery and Periodontics, Illinois: Quintessence Publishing. 1999: 83-102.

27. Hou R, Chen F, Yang Y, et al. Comparative study between coral-mesenchymal stem cells-rhBMP-2 composite and auto-bone-graft in rabbit critical-sized cranial defect model. J Biomed Mater Res A. 2007; 80(1): 85-93, doi: 10.1002/ jbm.a.30840, indexed in Pubmed: 16960828.

28. Huang B, Sun Y, Maciejewska I, et al. Distribution of SIBLING proteins in the organic and inorganic phases of rat dentin and bone. Eur J Oral Sci. 2008; 116(2): 104-112, doi: 10.1111/j.1600-0722.2008.00522.x, indexed in Pubmed: 18353003.

29. Ihara H, Denhardt DT, Furuya K, et al. Parathyroid hormone-induced bone resorption does not occur in the absence of osteopontin. J Biol Chem. 2001; 276(16): 13065-13071, doi: 10.1074/jbc.M010938200, indexed in Pubmed: 11278791.

30. Isler SC, Unsal B, Soysal F, et al. The effects of ozone therapy as an adjunct to the surgical treatment of peri-implantitis. J Periodontal Implant Sci. 2018; 48(3): 136-151, doi: 10.5051/jpis.2018.48.3.136, indexed in Pubmed: 29984044.

31. Jakus AE, Rutz AL, Jordan SW, et al. Hyperelastic "bone": A highly versatile, growth factor-free, osteoregenerative, scalable, and surgically friendly biomaterial. Sci Transl Med. 2016; 8(358): 358ra127, doi: 10.1126/scitranslmed. aaf7704, indexed in Pubmed: 27683552.
32. Kan B, Sencimen M, Bayar GR, et al. Histomorphometric and microtomographic evaluation of the effects of hyperbaric oxygen and systemic ozone, used alone and in combination, on calvarial defect healing in rats. J Oral Maxillofac Surg. 2015; 73(6): 1231.e1-1231.10, doi: 10.1016/j. joms.2015.02.018, indexed in Pubmed: 25981839.

33. Kazancioglu HO, Ezirganli S, Aydin MS. Effects of laser and ozone therapies on bone healing in the calvarial defects. J Craniofac Surg. 2013; 24(6): 2141-2146, doi: 10.1097/ SCS.0b013e3182a244ae, indexed in Pubmed: 24220424.

34. Kelm RJ, et al. Jr, Swords NA, Orfeo T, Osteonectin in matrix remodeling. A plasminogen-osteonectin collagen complex. J Biol Chem. 1994; 269(48): 30147-30153.

35. Khojasteh A, Eslaminejad MB, Nazarian H. Mesenchymal stem cells enhance bone regeneration in rat calvarial critical size defects more than platelete-rich plasma. Oral Surg Oral Med Oral Pathol Oral Radiol Endod. 2008; 106(3): 356-62; discussion 363, doi: 10.1016/j. tripleo.2007.10.017, indexed in Pubmed: 18424120.

36. Kim KS, Lee JY, Kang YM, et al. Small intestine submucosa sponge for in vivo support of tissue-engineered bone formation in the presence of rat bone marrow stem cells. Biomaterials. 2010; 31(6): 1104-1113, doi: 10.1016/j. biomaterials.2009.10.020, indexed in Pubmed: 19854502.

37. Klein-Nulend J, Roelofsen J, Semeins CM, et al. Mechanical stimulation of osteopontin mRNA expression and synthesis in bone cell cultures. J Cell Physiol. 1997; 170(2): 174-181, doi: 10.1002/(SICI)1097-4652(199702)170:2<174::AIDJCP9>3.0.CO;2-L, indexed in Pubmed: 9009146.

38. Koparal M, Irtegün S, Alan $\mathrm{H}$, et al. Effects of Melatonin on Tibia Bone Defects in Rats. Int J Morphol. 2016; 34(2): 763-769, doi: 10.4067/s0717-95022016000200053.

39. Laçin N, Kaya B, Deveci E, et al. Comparative evaluation of ozone treatment in critical size bone defects reconstructed with alloplastic bone grafts. Int J Clin Med. 2018; 09(07): 566-579, doi: 10.4236/ijcm.2018.97048.

40. Lee MK, DeConde AS, Lee M, et al. Biomimetic scaffolds facilitate healing of critical-sized segmental mandibular defects. Am J Otolaryngol. 2015; 36(1): 1-6, doi: 10.1016/j. amjoto.2014.06.007, indexed in Pubmed: 25109658.

41. Malard O, Guicheux J, Bouler JM, et al. Calcium phosphate scaffold and bone marrow for bone reconstruction in irradiated area: a dog study. Bone. 2005; 36(2): 323-330, doi: 10.1016/j.bone.2004.07.018, indexed in Pubmed: 15780959.

42. Miron RJ, Zhang Q, Sculean A, et al. Osteoinductive potential of 4 commonly employed bone grafts. Clin Oral Investig. 2016; 20(8): 2259-2265, doi: 10.1007/s00784016-1724-4, indexed in Pubmed: 26814714.

43. Ono N, Nakashima K, Rittling SR, et al. Osteopontin negatively regulates parathyroid hormone receptor signaling in osteoblasts. J Biol Chem. 2008; 283(28): 19400-19409, doi: 10.1074/jbc.M800005200, indexed in Pubmed: 18417476.

44. Ozdemir B, Kurtis B, Tuter G, et al. Osteocalcin and osteonectin expression after double application of platelet-rich plasma in rabbits. J Istanb Univ Fac Dent. 2016; 50(2): 1-9, doi: 10.17096/jiufd.40536, indexed in Pubmed: 28955559.

45. Ozdemir H, Toker H, Balcı H, et al. Effect of ozone therapy on autogenous bone graft healing in calvarial defects: 
a histologic and histometric study in rats. J Periodontal Res. 2013; 48(6): 722-726, doi: 10.1111/jre.12060, indexed in Pubmed: 23452156.

46. Ozeç I, Kiliç E, Gümüş C, et al. Effect of local simvastatin application on mandibular defects. J Craniofac Surg. 2007; 18(3): 546-550, doi: 10.1097/scs.0b013e318052ff05, indexed in Pubmed: 17538316.

47. Page $D$, Laskin $D$. Tissue response at the bone-implant interface in a hydroxylapatite augmented mandibular ridge. J Oral Maxillofac Surg. 1987; 45(4): 356-358, doi: 10.1016/0278-2391(87)90360-0.

48. Pal U, Mishra N. Placement of implants in an ossifying fibroma defect obliterated with demineralized, freeze-dried bone allograft and Plasma-rich growth factor. Contemp Clin Dent. 2012; 3(4): 471-474, doi: 10.4103/0976237X.107444, indexed in Pubmed: 23633812.

49. Pati F, Song TH, Rijal G, et al. Ornamenting 3D printed scaffolds with cell-laid extracellular matrix for bone tissue regeneration. Biomaterials. 2015; 37: 230-241, doi: 10.1016/j. biomaterials.2014.10.012, indexed in Pubmed: 25453953.

50. Pearce Al, Richards RG, Milz S, et al. Animal models for implant biomaterial research in bone: a review. Eur Cell Mater. 2007; 13: 1-10, doi: 10.22203/ecm.v013a01, indexed in Pubmed: 17334975.

51. Qin C, Baba O, Butler WT. Post-translational modifications of sibling proteins and their roles in osteogenesis and dentinogenesis. Crit Rev Oral Biol Med. 2004; 15(3): 126-136, doi: 10. 1177/154411130401500302, indexed in Pubmed: 15187031.

52. Rasouli-Ghahroudi AA, Rokn A, Abdollahi M, et al. Effect of semelil, an herbal selenium-based medicine, on new bone formation in calvarium of rabbits. Biomed Res Int. 2018; 2018: 2860367 , doi: $10.1155 / 2018 / 2860367$, indexed in Pubmed: 29682529.

53. Reichert JC, Epari DR, Wullschleger ME, et al. Establishment of a preclinical ovine model for tibial segmental bone defect repair by applying bone tissue engineering strategies. Tissue Eng Part B Rev. 2010; 16(1): 93-104, doi: 10.1089/ ten.TEB.2009.0455, indexed in Pubmed: 19795978.

54. Roach HI. Why does bone matrix contain non-collagenous proteins? The possible roles of osteocalcin, osteonectin, osteopontin and bone sialoprotein in bone mineralisation and resorption. Cell Biol Int. 1994; 18(6): 617-628, doi: 10.1006/ cbir.1994.1088, indexed in Pubmed: 8075622.

55. Rodriguez $R$, Kondo $H$, Nyan $M$, et al. Implantation of green tea catechin $\alpha$-tricalcium phosphate combination enhances bone repair in rat skull defects. J Biomed Mater Res B Appl Biomater. 2011; 98(2): 263-271, doi: 10.1002/ jbm.b.31848, indexed in Pubmed: 21591251.

56. Roux BM, Akar B, Zhou W, et al. Preformed vascular networks survive and enhance vascularization in critical sized cranial defects. Tissue Eng Part A. 2018; 24(21-22): 1603-1615, doi: 10.1089/ten.TEA.2017.0493, indexed in Pubmed: 30019616.

57. Sagai M, Bocci V. Mechanisms of action involved in ozone therapy: is healing induced via a mild oxidative stress? Med Gas Res. 2011; 1: 29, doi: 10.1186/2045-9912-1-29, indexed in Pubmed: 22185664.

58. Saito A, Ooki A, Nakamura T, et al. Targeted reversion of induced pluripotent stem cells from patients with human cleidocranial dysplasia improves bone regeneration in a rat calvarial bone defect model. Stem Cell Res Ther. 2018; 9(1): 12, doi: 10.1186/ s13287-017-0754-4, indexed in Pubmed: 29357927.

59. Sakata $Y$, Ueno T, Kagawa T, et al. Osteogenic potential of cultured human periosteum-derived cells - a pilot study of human cell transplantation into a rat calvarial defect model. J Craniomaxillofac Surg. 2006; 34(8): 461-465, doi: 10.1016/j. jcms.2006.07.861, indexed in Pubmed: 17157522.

60. Sodek J, Batista Da Silva AP, Zohar R. Osteopontin and mucosal protection. J Dent Res. 2006; 85(5): 404-415, doi: 10.1 177/154405910608500503, indexed in Pubmed: 16632752.

61. Sodek J, Ganss B, McKee MD. Osteopontin. Crit Rev Oral Biol Med. 2000; 11(3): 279-303.

62. Spicer PP, Kretlow JD, Young S, et al. Evaluation of bone regeneration using the rat critical size calvarial defect. Nat Protoc. 2012; 7(10): 1918-1929, doi: 10.1038/ nprot.2012.113, indexed in Pubmed: 23018195.

63. Standal T, Borset M, Sundan A. Role of osteopontin in adhesion, migration, cell survival and bone remodeling. Exp Oncol. 2004; 26(3): 179-184, indexed in Pubmed: 15494684.

64. Toita R, Tsuru K, Ishikawa K. A superhydrophilic titanium implant functionalized by ozone gas modulates bone marrow cell and macrophage responses. J Mater Sci Mater Med. 2016; 27(8): 127, doi: 10.1007/s10856-016-5741-2, indexed in Pubmed: 27344451.

65. Thurner PJ, Chen CG, lonova-Martin S, et al. Osteopontin deficiency increases bone fragility but preserves bone mass. Bone. 2010; 46(6): 1564-1573, doi: 10.1016/j. bone.2010.02.014, indexed in Pubmed: 20171304.

66. Tricot M, Deleu PA, Detrembleur C, et al. Clinical assessment of 115 cases of hindfoot fusion with two different types of graft: allograft $+\mathrm{dbm}+$ bone marrow aspirate versus autograft+DBM. Orthop Traumatol Surg Res. 2017; 103(5): 697-702, doi: 10.1016/j.otsr.2017.03.014, indexed in Pubmed: 28416462.

67. Tshamala M, van Bree H. Osteoinductive properties of the bone marrow--myth or reality. Vet Comp Orthop Traumatol. 2006; 19(3): 133-141, indexed in Pubmed: 16971995.

68. Tye CE, Rattray KR, Warner KJ, et al. Delineation of the hydroxyapatite-nucleating domains of bone sialoprotein. J Biol Chem. 2003; 278(10): 7949-7955, doi: 10.1074/jbc. M211915200, indexed in Pubmed: 12493752.

69. Wang X, Zeng D, Weng W, et al. Alendronate delivery on amino modified mesoporous bioactive glass scaffolds to enhance bone regeneration in osteoporosis rats. Artif Cells Nanomed Biotechnol. 2018; 46(sup2): 171-181, doi: 10.1080 /21691401.2018.1453825, indexed in Pubmed: 29688044.

70. Wang YH, Wu JY, Kong SC, et al. Low power laser irradiation and human adipose-derived stem cell treatments promote bone regeneration in critical-sized calvarial defects in rats. PLoS One. 2018; 13(4): e0195337, doi: 10.1371/ journal.pone.0195337, indexed in Pubmed: 29621288.

71. Yang Y, Cui Q, Sahai N. How does bone sialoprotein promote the nucleation of hydroxyapatite? A molecular dynamics study using model peptides of different conformations. Langmuir. 2010; 26(12): 9848-9859, doi: 10.1021/la100192z, indexed in Pubmed: 20438109.

72. Yang Yi, Hallgrimsson B, Putnins EE. Craniofacial defect regeneration using engineered bone marrow mesenchymal stromal cells. J Biomed Mater Res A. 2011; 99(1): 74-85, doi: 10.1002/jbm.a.33155, indexed in Pubmed: 21800417. 